Portland State University

PDXScholar

Spring 2021

\title{
Anatomical Analysis of Somatic Mutation Accumulation in Mimulus guttatus
}

Amanda Burrell

Portland State University

Follow this and additional works at: https://pdxscholar.library.pdx.edu/honorstheses

Part of the Plant Biology Commons, and the Plant Breeding and Genetics Commons Let us know how access to this document benefits you.

Recommended Citation

Burrell, Amanda, "Anatomical Analysis of Somatic Mutation Accumulation in Mimulus guttatus" (2021). University Honors Theses. Paper 1122.

https://doi.org/10.15760/honors.1153

This Thesis is brought to you for free and open access. It has been accepted for inclusion in University Honors Theses by an authorized administrator of PDXScholar. Please contact us if we can make this document more accessible: pdxscholar@pdx.edu. 
Anatomical Analysis of Somatic Mutation Accumulation in Mimulus guttatus

Amanda Burrell

Portland State University

Thesis Advisor

Mitchell Cruzan 


\begin{abstract}
Plants are seemingly immortal in their abilities to survive long periods of dormancy in different life stages, live for thousands of years, and even grow into whole forests from one clone, all through a series of mitotic and meiotic events, but how many mutations do plants acquire in their lifetime? And just how many of these mutations are heritable? To answer these questions, first we must answer: how many cell divisions are there in the length of a stem? The purpose of this study is to answer just that by establishing a protocol for estimating the number of germ cell divisions required for a stem growth. I used a histological approach to generate a reliable model of stem growth and number of cells required for stem construction for downstream genomic analyses of somatic mutation rate to estimate the per-cell generation mutation rate along the length of a stem. Longitudinal and cross-sectional stem samples of an emerging model plant, Mimulus guttatus were made and stained to identify individual cells. Cells were counted to estimate the number of cells produced from meristematic cells in a standard length of stem for early growth and for mature stems (late growth). I used these estimates with a model for cell population growth to estimate the number of cell generations required to construct the stem when starting with different germ cell population sizes. In a separate study, sequential samples will be sequenced for transcribed regions (the exome) to identify new mutations that arise through mitotic division. Meristematic cell division rates will be combined with information on mutation rates to determine a per cell generation mutation rate, which will be used to estimate the potential for somatic mutation accumulation during vegetative growth.
\end{abstract}




\section{Background}

New mutations are the basis for genetic variability in populations. Any research aimed at understanding the mechanism for heritability of somatic mutations can have major implications across all disciplines relating to rates of evolution. While estimating mutation rate indirectly has created a vast knowledge in disciplines relating to evolution and the natural world as a whole, directly measuring mutation rate in individuals can aid in resolving the hypotheses that surround the idea of a plant germline or lack thereof. Studying mutation rate in individuals will allow us to see new mutations as they occur with vegetative growth, possibly the propagation or disappearance (due to cell lineage selection) of these mutations, and with further research, the heritability of these somatic mutations.

Organisms vary in their ability to transmit mutations acquired during meiosis and mitosis. Unicellular micro-organisms acquire most genetic variability through errors in DNA replication during mitosis (somatic mutations; Elena and Lenski 2003). Animals have a segregated germline that prevents inheritance of somatic mutations, so the primary source of mutations is through meiosis during the production of gametes (Beerenwinkel et al. 2015). Plants are unique in that their germ cells contribute to vegetative plant structures as well as reproductive structures, meaning that mutations accumulated through mitosis can be heritable (Klekowski et al. 1984). Given that many plants exhibit indeterminate growth with extensive amounts of mitotic divisions, the potential for mutational load should theoretically be high, but this expected mutational load is not observed across plant generations (Gaut 2011). It has been proposed that this is due to selection among germ cell lineages where more fit lineages will outpace and replace less fit lineages (Cruzan 2018). By performing DNA sequencing along the length of a 
stem, one can observe the frequency of somatic mutations, allowing a direct estimation of somatic mutation rates (J.A. Schwoch, personal communication). While it would be desirable to estimate the per-cell-generation mutation rate, there is no direct method established for estimating how many germ cell divisions have occurred to produce a length of a stem.

There are two key hypotheses surrounding the germ cells of plants and the various ways in which plants deal with mutation accumulation. The Plant Germline hypothesis $(\mathrm{PGH})(\mathrm{Cruzan}$ 2018) operates under the assumption that plants have a set of cells in the meristem that undergo limited mitotic division, like a germline in animals (Burien et al. 2016). A competing hypothesis, the Somatic Mutation Accumulation hypothesis (SMAH), assumes that cells in the meristem are not limited in their mitotic division and any somatic mutations that arise have the potential to be passed onto the progeny due to the developmental nature of gametes in plants (Scofield 2006; Cruzan et al. 2019). By observing the cells in the length of a stem as a population, one can observe each cell as an individual in the population. New mutations acquired through mitotic division therefore increase genetic variation within the population and this can lead to selection of cell lineages that originated from cells in the meristem as they accumulate mutations that may be beneficial or detrimental to the cell lineage (Cruzan 2018).

Here I develop a protocol to quantify the average number of germ cell divisions required to construct a length of a stem. In collaboration with genetic sequencing data, the information I collect will allow us to determine how many new mutations have happened per cell division, giving us a direct estimate of the mutation rate. This is not only a novel approach, but very informative for all studies in the future that aim to educate estimates of mutation rate at the individual level. 


\section{Methods}

The perennial, Mimulus guttatus, is a prime candidate for this research as the individuals exhibit indeterminant growth patterns and so are inherently exposed to the opportunity for clonal evolution, making it ideal for testing the accumulation of somatic mutations in cell lineages within a stem. Individual rosettes can be rooted so multiple ramets from a single genet can be compared within and between treatments over reasonable periods of time. The Mimulus guttatus individuals were grown in the PSU Research Greenhouse from September of 2019 to June of 2020. These plants were then transferred outdoors to an East-facing wall in the May of 2020 and then were dissected in June of 2020.

Internodes are the lengths of stem between the nodes (where leaf growth occurs on the stem). The section of stem where leaf growth occurs has densely packed cells. These densely packed cells also extend in convoluted planes, making histological observation difficult for our purposes. The structure of cells in the internodes has easily observable planes and is better suited for the approach of this project. The 1st, 3rd, and 5th internodes were sampled for staining. This sampling strategy was adopted to make data collection efficient, and to also give enough room to capture any variation between internodes. The anticipated variation in cell size that may occur along the length of the stem is due to cell elongation. A sample of the internode was cut to isolate from the nodes and this was divided into three equal pieces; towards the ends of each internode, transverse sections were made as thin as possible, calling the old growth BC (Bottom Cut), and the new growth TC (Top Cut), the center piece was cut longitudinally and as thin as possible, it was called the LC (Longitudinal Cut). The cuts were sampled this way to ensure that any variation of cell size could be accounted for within internodes (see Figure 1). These samples 
were organized by Stem, Internode, and Cut. Each cut was kept in its respective microcentrifuge tube for data analysis.

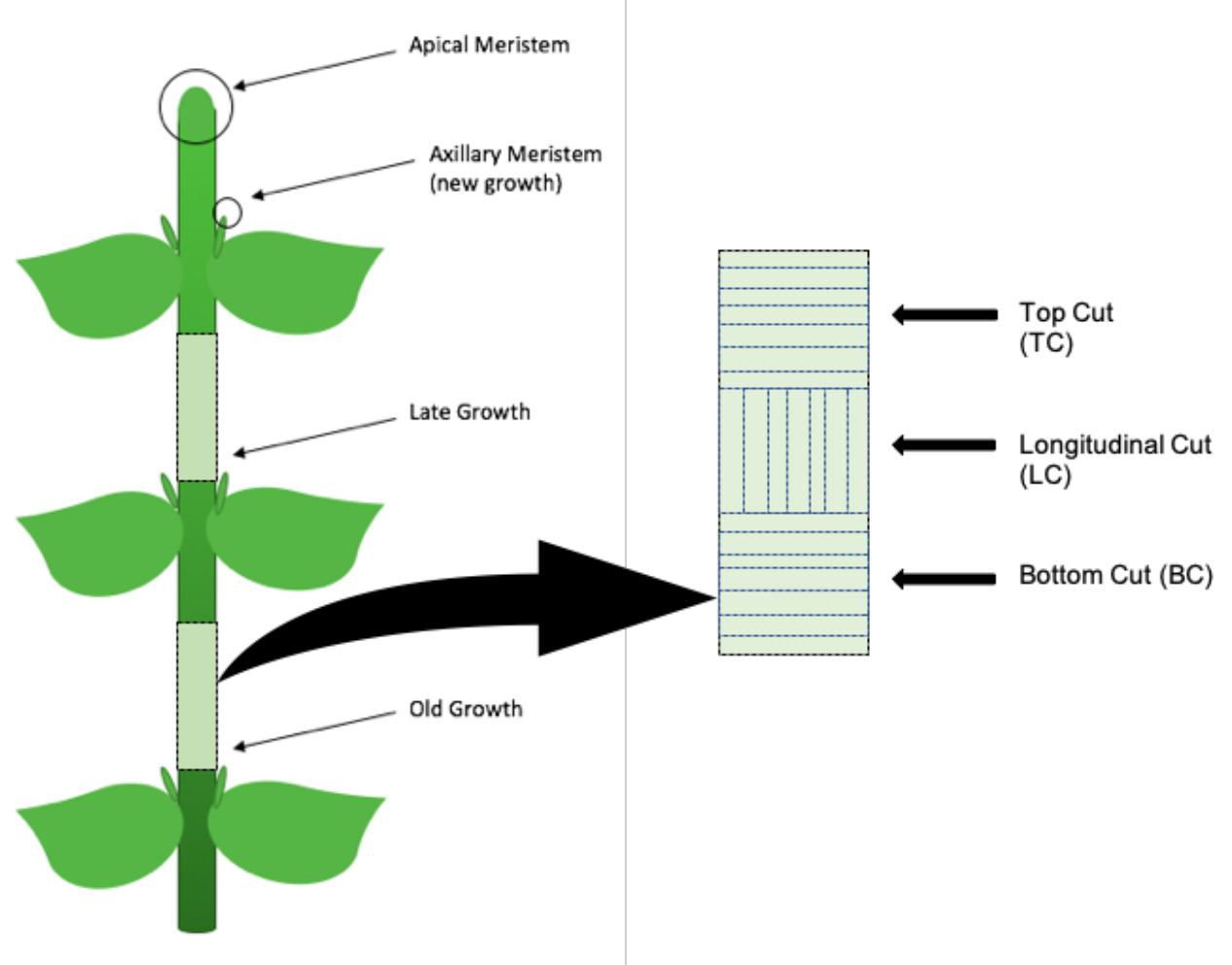

Figure 1: Sampling Strategy Along Length of Stem

To visualize the cell walls, one drop of Basic Fuchsin stain was added to each microcentrifuge tube and then the cuts were added to the tube, following this FAA fixative (without formalin) was added to the tube. After 24 hours, the cuts were taken out of the tube and wet-mounted for observation. The samples were observed under the dissecting scope (if transverse) or under the compound microscope (if longitudinal). Photos were captured at total magnification range between $21 \mathrm{X}$ to $135 \mathrm{X}$ which of the transverse cut of the stem where the stem shape and cell walls were distinguishable. Longitudinal cuts were imaged using total magnification range of $120 \mathrm{X}$ to $1200 \mathrm{X}$ to clearly distinguish densely packed cells. The two 
cleanest cuts were photographed and then these cuts were preserved in the same FAA/Basic Fuchsin stain mixture in the appropriate centrifuge tube. Broken and thick cuts were discarded.

Data collection was done through the opensource program ImageJ; using inverted image overlays, oval shape overlays, line overlays, measurement tools, and counting tools to create several estimations for measurement. The estimations created were; an estimation on the area of the whole stem around the epidermis (where visible), around the outside of the vascular bundle, around the inside of the vascular bundle, and around aerenchyma (when present). When the whole cut of the stem was not visible in the photo, the oval shape was extrapolated to represent the absent image as closely as possible. The entire area was divided into fourths or eighths,

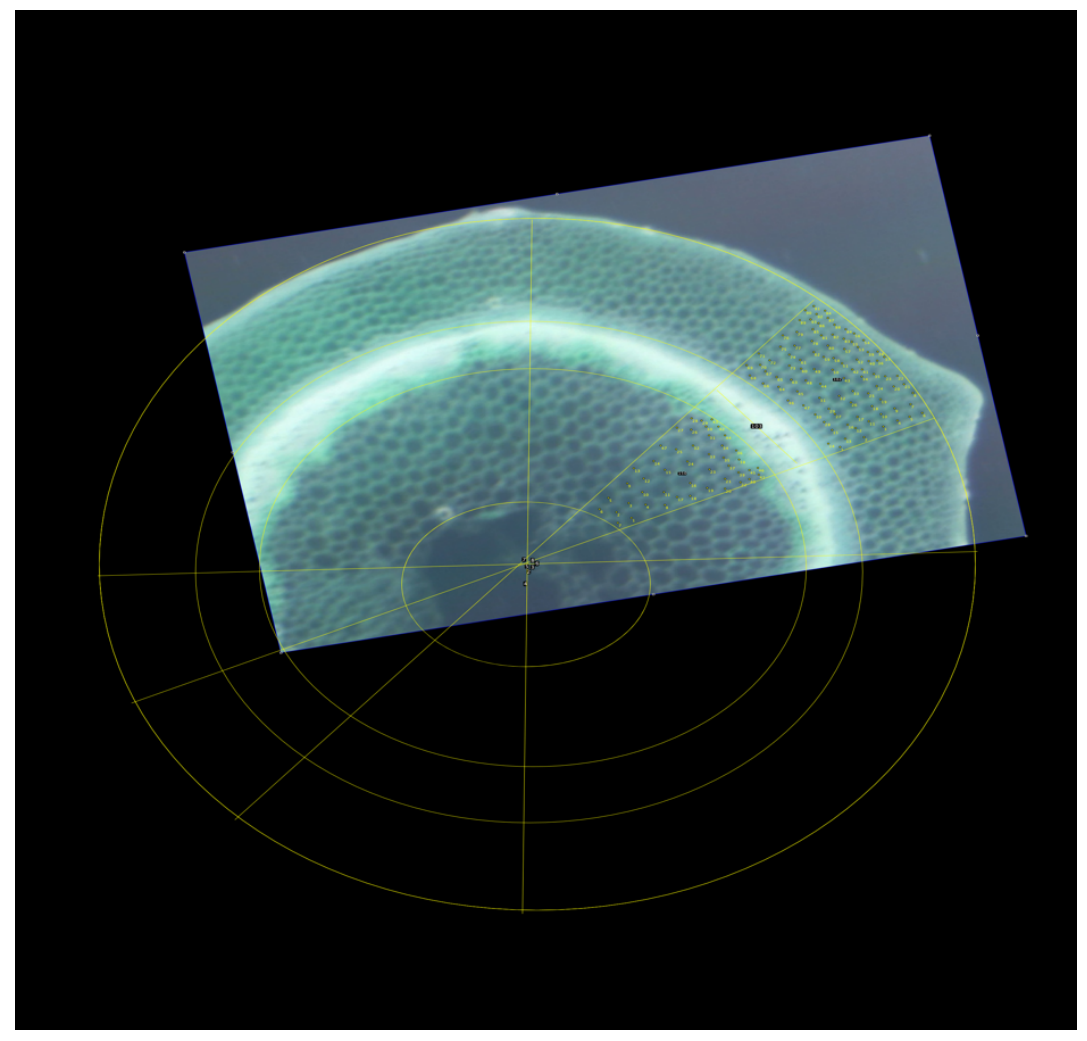

where appropriate. The cell counts were taken in the portion that had the most distinct cell walls, and then this count was multiplied by the appropriate multiplier to get the cell count for the entire transverse cut (see Figure 2). The area of the visible cells, in tandem with the cell count allows for a calculation of average area per cell.

Figure 2:Transverse Cut ImageJ Analyzed Sample 
The analysis of the longitudinal cuts was done by measuring two straight lines along a decided X-axis (running parallel to the length of the stem) and a Y-axis (running perpendicular to the length of the stem). Cell counts were taken for the cells that the straight lines intersected along the $\mathrm{X}$-axis and along the $\mathrm{Y}$-axis (see Figure 3). This allowed for the calculation of the average length of a cell.

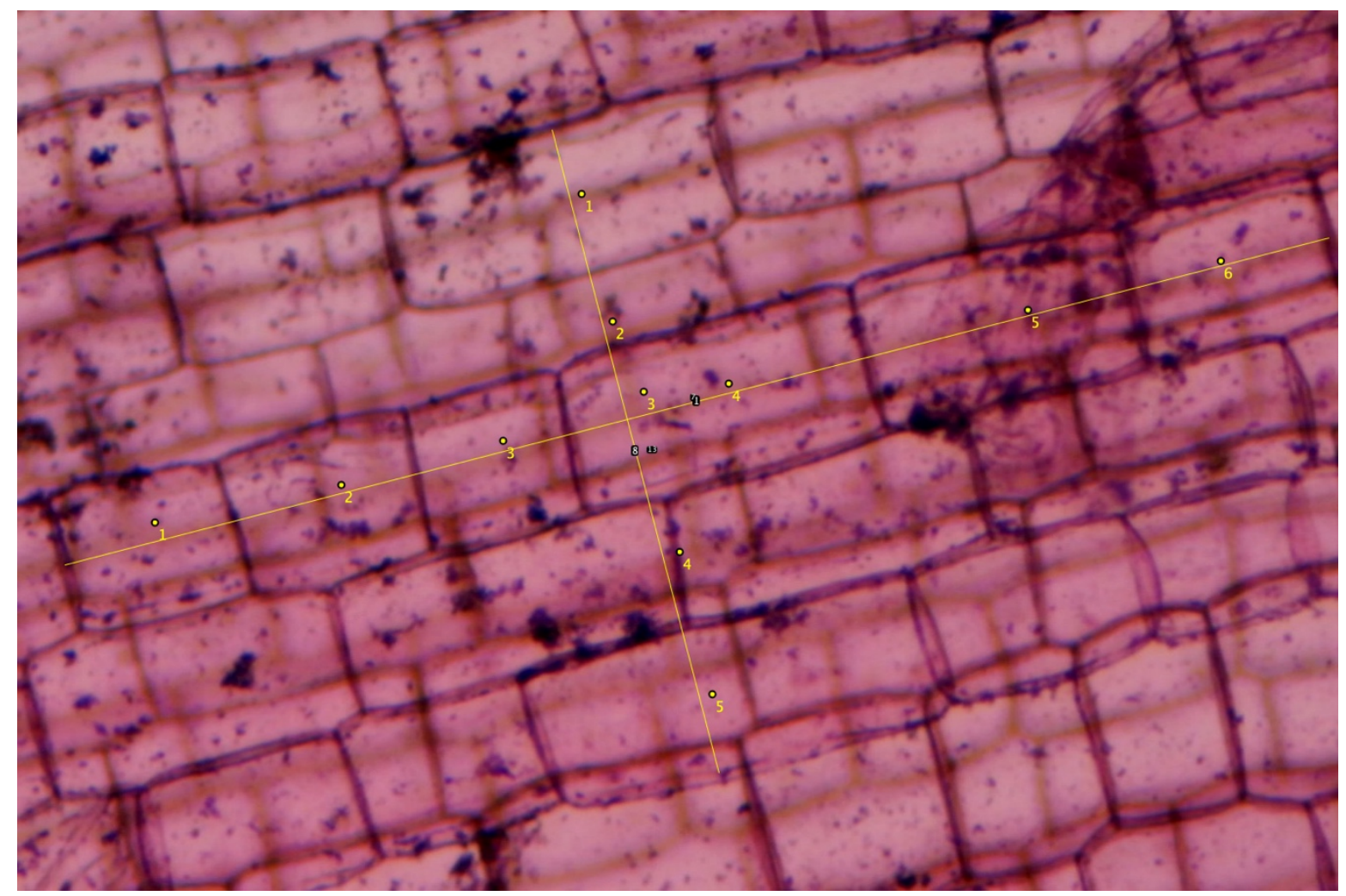

Figure 3: Longitudinal Cut ImageJ Analyzed from sample

\section{Results}

The average length of the cell and average area of each stem in tandem with the cell counts allows for a calculation of average cell length $\left(\mathrm{mm} /\right.$ cell), and average cell area $\left(\mathrm{mm}^{2} /\right.$ cell). The average amount of cells per length (mm/cell) multiplied by cells per area $\left(\mathrm{mm}^{2} / \mathrm{cell}\right)$, allows for the calculation of average amount of volume per cell $\left(\mathrm{mm}^{3} /\right.$ cell). The inverse of this is calculated by dividing 1 by the average amount of volume per cell $\left(\mathrm{mm}^{3} / \mathrm{cell}\right)$, to get average amount of 
cells per volume (cells $/ \mathrm{mm}^{3}$ ), which is specific to each stem. From here, each stem is given the same area and length to form a standard volume. From this standard volume, the estimated number of Parenchyma Cells in Stem Population can be calculated for each stem by using the average Parenchyma cells per volume $\left(\right.$ cells $\left./ \mathrm{mm}^{3}\right)$ (see Table 1).

Table 1: Analyzed Histological Measurements

\begin{tabular}{|c|c|c|c|c|c|c|c|c|c|c|c|c|c|c|}
\hline Stem & Internode & $\begin{array}{l}\text { Average } \\
\text { Hm/Xcell }\end{array}$ & $\begin{array}{l}\text { Average } \\
\mathrm{mm} / \mathrm{Xcell}\end{array}$ & $\begin{array}{l}\text { Average } \\
\text { Xcell/mm }\end{array}$ & $\begin{array}{l}\text { Area }\left(\mu m^{\wedge} 2\right) / \\
\text { Parenchyma } \\
\text { Cell }\end{array}$ & $\begin{array}{l}\text { Area }\left(m^{\wedge}{ }^{\wedge}\right) / \\
\text { Parenchyma } \\
\text { Cell }\end{array}$ & $\begin{array}{l}\text { Parenchyma } \\
\text { Cell/Area } \\
\left(m m^{\wedge} 2\right)\end{array}$ & $\begin{array}{l}\text { Total Pith and } \\
\text { Cortex Area } \\
\left(m m^{\wedge} 2\right)\end{array}$ & \begin{tabular}{|l} 
Parenchyma \\
Volume \\
$\left(m m^{\wedge} 3\right) /$ Cells
\end{tabular} & $\begin{array}{l}\text { Parenchyma } \\
\text { Cells/Nolume } \\
\left(m m^{\wedge} 3\right)\end{array}$ & $\begin{array}{l}\text { Average } \\
\text { Parenchyma } \\
\text { Cells/Nolume } \\
\left(\mathrm{mm}^{\mathrm{n} 3}\right)\end{array}$ & $\begin{array}{l}\text { Standard } \\
\text { Deviation }\end{array}$ & N & $\begin{array}{l}\text { Standard } \\
\text { Error }\end{array}$ \\
\hline 1 & 1 & \begin{tabular}{|l|}
276.8826 \\
\end{tabular} & \begin{tabular}{|l|}
0.2769 \\
\end{tabular} & \begin{tabular}{|r|}
3.6380 \\
\end{tabular} & 5891.2 & \begin{tabular}{|r}
.891 \\
\end{tabular} & \begin{tabular}{|l|l|}
0.1697 \\
\end{tabular} & \begin{tabular}{|l|}
7354.691 \\
\end{tabular} & \begin{tabular}{|l}
5891.182747 \\
\end{tabular} & 5.8912 & \multirow[b]{3}{*}{9.2242} & \multirow[b]{3}{*}{3.0582} & \multirow[b]{3}{*}{3} & \multirow[b]{3}{*}{1.7657} \\
\hline 1 & 3 & 189.2873 & 0.1893 & 5.3532 & 3293.4 & 3.293 & 0.3036 & 4535.859 & 3293.393616 & 9.8802 & & & & \\
\hline 1 & 5 & 108.4124 & 0.1084 & 9.2542 & 2380.2 & 2.380 & 0.4201 & 4170.180 & 2380.239489 & 11.9012 & & & & \\
\hline 2 & 1 & 316.8436 & 0.3168 & 3.1594 & 1328.6 & 1.329 & 0.7526 & 2806.078 & 2657.291355 & 1.3286 & \multirow[b]{3}{*}{6.4172} & \multirow[b]{3}{*}{14.0676} & \multirow[b]{3}{*}{2} & \multirow[b]{3}{*}{9.9473} \\
\hline 2 & 3 & & & & 7799.7 & 7.800 & 0.1282 & 15986.047 & & & & & & \\
\hline 2 & 5 & 308.2756 & 0.3083 & 3.3125 & 2301.1 & 2.301 & 0.4346 & 4892.660 & 4602.270274 & 11.5057 & & & & \\
\hline 3 & 1 & 263.1691 & 0.2632 & 3.8841 & 31400.3 & 31.400 & 0.0318 & 53853.388 & 94200.98854 & 31.4003 & \multirow[b]{3}{*}{18.0284} & \multirow[b]{3}{*}{3.7353} & \multirow[b]{3}{*}{3} & \multirow[b]{3}{*}{2.1566} \\
\hline 3 & 3 & 307.9889 & 0.3080 & 3.2963 & 3729.5 & 3.730 & 0.2681 & 5486.671 & 11188.57886 & 11.1886 & & & & \\
\hline 3 & 5 & 348.3816 & 0.3484 & 2.8722 & 2299.3 & 2.299 & 0.4349 & 2464.238 & 6897.857841 & 11.4964 & & & & \\
\hline 4 & 1 & 285.8025 & 0.2858 & 3.4992 & 4878.3 & 4.878 & 0.2050 & 9560.813 & 19513.20418 & 4.8783 & \multirow[b]{3}{*}{8.9591} & \multirow[b]{3}{*}{ \#DIV/0! } & \multirow[b]{3}{*}{1} & \multirow[b]{3}{*}{ \#DIV/0! } \\
\hline 4 & 3 & & & & 9540.6 & 9.541 & 0.1048 & 13117.910 & & & & & & \\
\hline 4 & 5 & 245.5338 & 0.2455 & 4.0935 & 2608.0 & 2.608 & 0.3834 & 1961.548 & 10431.93889 & 13.0399 & & & & \\
\hline 5 & 1 & & & & 4360.7 & 4.361 & 0.2293 & 7668.416 & & & \multirow[b]{3}{*}{24.9321} & \multirow[b]{3}{*}{19.9342} & \multirow[b]{3}{*}{3} & \multirow[b]{3}{*}{11.5090} \\
\hline 5 & 3 & 250.6683 & 0.2507 & 4.1364 & 3351.6 & 3.352 & 0.2984 & 3658.158 & 16757.75567 & 10.0547 & & & & \\
\hline 5 & 5 & 270.0239 & 0.2700 & 3.7037 & 7961.9 & 7.962 & 0.1256 & 7231.429 & 39809.51108 & 39.8095 & & & & \\
\hline 6 & 1 & 295.3585 & 0.2954 & 3.4067 & 1951.6 & 1.952 & 0.5124 & 2140.955 & 11709.52328 & 1.9516 & \multirow[b]{3}{*}{3.2816} & \multirow[b]{3}{*}{0.4997} & \multirow[b]{3}{*}{2} & \multirow[b]{3}{*}{0.3534} \\
\hline 6 & 3 & 282.5093 & 0.2825 & 3.5449 & 1433.3 & 1.433 & 0.6977 & 1076.641 & 8599.927211 & 4.3000 & & & & \\
\hline 6 & 5 & 286.7784 & 0.2868 & 3.5465 & 718.6 & 0.719 & 1.3915 & 702.606 & 4311.866529 & 3.5932 & & & & \\
\hline
\end{tabular}

The average number of Parenchyma cells in each cell was calculated using $100 \mathrm{~mm}$ for the length, and $40 \mathrm{~mm}$ for the diameter of the stem. This was used to estimate the cell population for each stem (see Table 2). The cell population was then used to estimate the number of cell generations as a function of initial cell populations in each stem, this represents germ cells in the central zone. The initial cell populations are: $2,5,8,10,30$. Because the exact number of cells in the central zone is still unknown, this allows for analysis of cell generations within a hypothetical range of initial germ cells. To obtain the cell generations, the formula: $X=r^{k} N$, where $\mathrm{X}$ is the end cell population size, $\mathrm{N}$ is the initial germ cell population size, $\mathrm{r}$ is the growth rate, and $\mathrm{k}$ is the number of cell generations (Todar 2020). The resulting number of cell generations assumes that every cell produces two daughter cells per division, making the growth rate exponential. 
This model also assumes that the total volume of the stem is occupied by parenchyma cells.

Rearranging to solve for $\mathrm{k}$, the formula becomes: $k=\frac{[\log (X)-\log (N)]}{\log (r)}$

Table 2: Calculated Cell Population Estimation

\begin{tabular}{|r|c|r|r|l|}
\hline & $\begin{array}{l}\text { Stem } \\
\text { Transverse } \\
\text { Area } \\
\left(\mathrm{mm}^{\wedge} 2\right)\end{array}$ & $\begin{array}{l}\text { ltem length } \\
(\mathrm{mm})\end{array}$ & $\begin{array}{l}\text { Volume of } \\
\text { stem } \\
\left(\mathrm{mm}^{\wedge} \mathbf{3}\right)\end{array}$ & $\begin{array}{l}\text { Parenchyma } \\
\text { cells in stem } \\
\text { population } \\
(\mathrm{X})\end{array}$ \\
\hline 1 & 5026.5500 & 100 & 502655 & 1027243.956 \\
\hline 2 & 5026.5500 & 100 & 502655 & 959408.3333 \\
\hline 3 & 5026.5500 & 100 & 502655 & 378113.1046 \\
\hline 5 & 5026.5500 & 100 & 502655 & 427092.3054 \\
\hline 6 & 5026.5500 & 100 & 502655 & 1533741.837 \\
\hline
\end{tabular}

The total number of Cell Generations can be visualized in the matrix of Table 3. The average number of Cell Generations per Initial Population can also be visualized in Figure 4, where each bar has a standard error of 0.6386 cell generations. In this figure, we can see that a larger initial cell population yields a smaller number of cell generations to reach the same final cell population.

Table 3: Cell Generations as a Function of Initial Cell Population and Stem

\begin{tabular}{|c|c|c|c|c|c|}
\hline \multirow{4}{*}{ Stem } & \multicolumn{5}{|c|}{ Average Cell Generations per Initial Cell Population (k) } \\
\hline & 4.8578 & 3.5359 & 2.8578 & 2.5359 & 0.9510 \\
\hline & \multicolumn{5}{|c|}{ Cell generations ( $\mathrm{k}$ ) } \\
\hline & 5.01167359 & 3.6897455 & 3.01167359 & 2.6897455 & 1.104782999 \\
\hline 2 & 4.98200349 & 3.66007539 & 2.98200349 & 2.66007539 & 1.075112891 \\
\hline 3 & 4.57762173 & 3.25569363 & 2.57762173 & 2.25569363 & 0.670731134 \\
\hline 4 & 4.75948953 & 3.43756143 & 2.75948953 & 2.43756143 & 0.852598933 \\
\hline 5 & 4.63052175 & 3.30859365 & 2.63052175 & 2.30859365 & 0.723631151 \\
\hline \multirow[t]{3}{*}{6} & 5.18575226 & 3.86382417 & 3.18575226 & 2.86382417 & 1.278861669 \\
\hline & 2 & 5 & 8 & 10 & 30 \\
\hline & \multicolumn{5}{|c|}{ Initial Cell Population (N) } \\
\hline
\end{tabular}




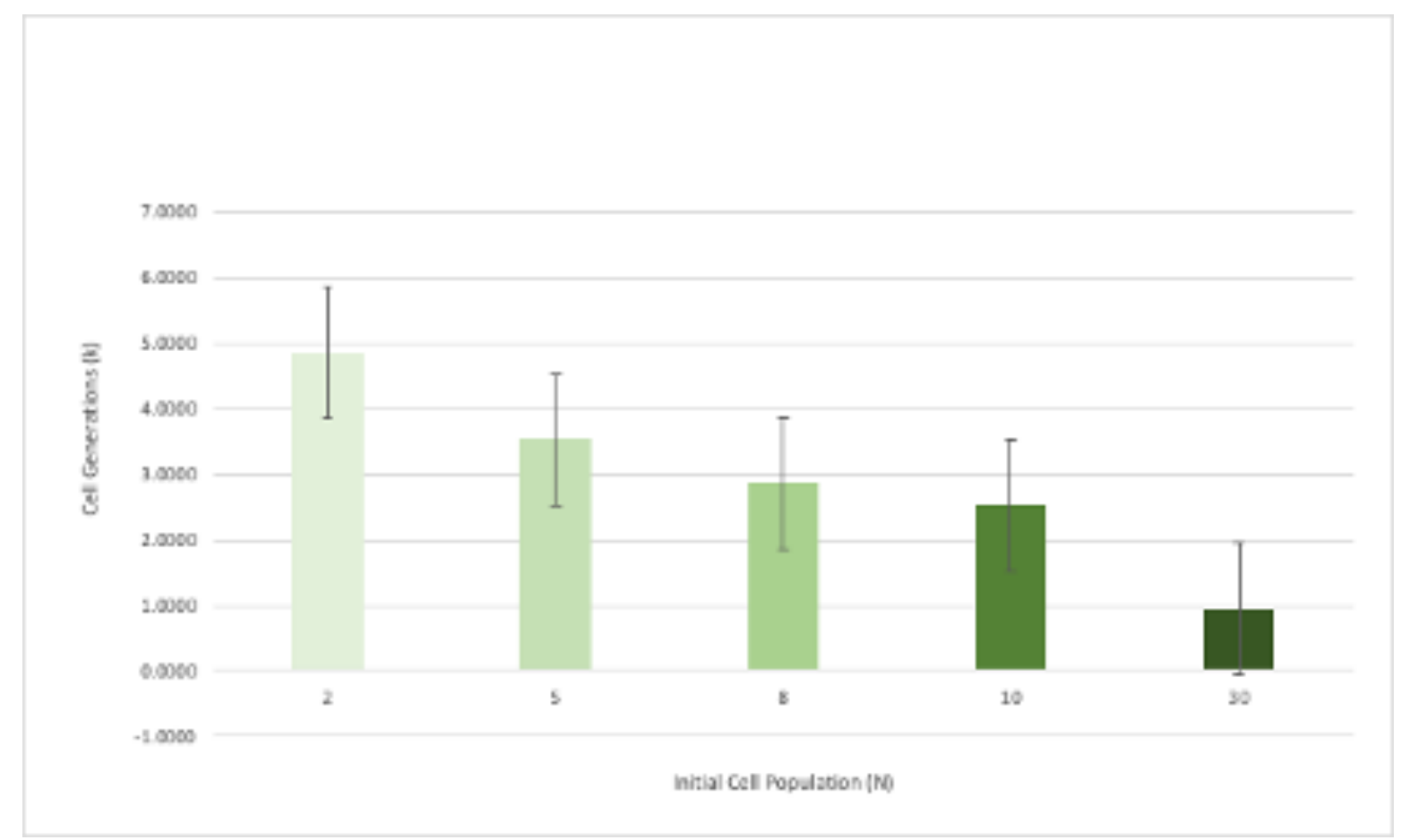

Figure 4: Cell Generations ( $k$ ) as Modeled by All Stems

\section{Discussion}

This model demonstrated that a smaller initial cell population required less cell generations to reach the same final cell population as a stem with a larger initial cell population. The error bars for the model with 30 cells in the initial cell population demonstrated that the error for this specific model may be too great for this initial cell population to be significant. As new research furthers knowledge about the number of cells in the central zone (initial cell population), the model can be adjusted without compromising the theoretical value of these findings.

In order to orient this model to real rates of mitosis in a plant stem, it would be beneficial to create a mitotic index of the cells at the apical meristem of each individual plant stem. A Mitotic index would improve the model by informing the number of cells undergoing mitosis during the time of observation. This would help add a time restriction to the model as the math behind the current model assumes that all divisions happening in the same instant, with no spatial limitations. Future studies may incorporate time of growth to get accurate portrayal of cell 
generations, due to the inherent nature of plant growth. Bacterial population growth rates, which inspired this model, do not account for the spatial limitations of plant tissue. It will be important to evaluate how this affects the rate of growth and the cell generations.

To account for cells in vascular and dermal tissue it would be imperative to consider imaging at a higher resolution, and to use a microtome to obtain thinner cuts and clearer imaging of plant tissues. Using stains and counter stains that allow for the visualization of different tissues would be important for resolving the generalizations made in this approach.

This project has created a model to educate further investigation of the existence of a plant germline. This research found that the number of hypothetical cell generations for the cell population in the length of a $100 \mathrm{~mm}$ stem came to be between 4.8578 , with an initial cell population of 2 cells, ranging to 2.5359 cell generations for an initial cell population of 10 cells. Pairing this method for determining cell population with DNA sequencing will allow for a direct measurement of base pair changes per cell division. This research serves not only as a novel approach to resolving the somatic mutation accumulation hypothesis, but also as a tool for studying plant mutation heritability and phenotypic expression in the context of rapidly changing climates. 


\section{Literature Cited}

Baer, C. F., Miyamoto, M. M., \& Denver, D. R. (2007). Mutation rate variation in multicellular eukaryotes: causes and consequences. Nature Reviews Genetics, 8(8), 619631. doi:10.1038/nrg2158

Beerenwinkel N, Schwarz RF, Gerstung M, Markowetz F. Cancer evolution: mathematical models and computational inference. Syst Biol. 2015 Jan;64(1):e1-25. doi: 10.1093/sysbio/syu081. Epub 2014 Oct 7. PMID: 25293804; PMCID: PMC4265145.

Burian, Agata, et al. "Patterns of Stem Cell Divisions Contribute to Plant Longevity." Current Biology, vol. 26, no. 11, 2016, pp. 1385-1394., doi:10.1016/j.cub.2016.03.067.

Cruzan, Mitchell B. Evolutionary Biology: a Plant Perspective. Oxford University Press, 2018.

Cruzan M.B., Streisfeld M.A., Schwoch J. A. 2019. "Phenotypic effects of somatic mutations accumulating during vegetative growth." bioRxiv DOI:10.1101/392175.

Elena SF, Lenski RE. Evolution experiments with microorganisms: the dynamics and genetic bases of adaptation. Nat Rev Genet. 2003 Jun;4(6):457-69. doi: 10.1038/nrg1088. PMID: 12776215.

Gaut, Brandon, et al. "The Patterns and Causes of Variation in Plant Nucleotide Substitution Rates." Annual Review of Ecology, Evolution, and Systematics, vol. 42, no. 1, Annual Reviews, Dec. 2011, pp. 245-266. Crossref, doi:10.1146/annurev-ecolsys-102710145119.

Klekowski, Edward J., and Nina Kazarinova-Fukshansky. "Shoot Apical Meristems and Mutation: Selective Loss of Disadvantageous Cell Genotypes." American Journal of Botany, vol. 71, no. 1, 1984, pp. 28-34. JSTOR, www.jstor.org/stable/2443620. Accessed 11 Feb. 2021.

Schultz, Stewart T., and Douglas G. Scofield. "Mutation Accumulation in Real Branches: Fitness Assays for Genomic Deleterious Mutation Rate and Effect in Large-Statured Plants." The American Naturalist, vol. 174, no. 2, 2009, pp. 163-175., doi:10.1086/600100.

Scofield, D. G. "Medial Pith Cells per Meter in Twigs as a Proxy for Mitotic Growth Rate $(/ \mathrm{m})$ in the Apical Meristem." American Journal of Botany, vol. 93, no. 12, 2006, pp. 1740-1747., doi:10.3732/ajb.93.12.1740.

Kenneth Todar, Madison. Growth of Bacterial Populations, Kenneth Todar, 2020, textbookofbacteriology.net/growth_3.html. 
Yao, Y., \& Kovalchuk, I. (2011). "Abiotic stress leads to somatic and heritable changes in homologous recombination frequency, point mutation frequency and microsatellite stability in Arabidopsis plants. Mutation Research/Fundamental and Molecular Mechanisms of Mutagenesis" 707(1-2), 61-66. doi:10.1016/j.mrfmmm.2010.12.013

\section{Materials}

Feather razor blades, Various sizes of tweezers, Microcentrifuge $1.5 \mathrm{~mL}$ tubes, Disposable Pipettes, Glass Slides, Coverslips, Ruler, Micrometer, FAA (Farmer's Fixative without Formalin), Basic Fuchsin dye, ImageJ, Six flowering mimulus guttatus individuals transplanted from the South side of the Science Building on PSU's main campus, Celestron 5 MP Camera, Leica Compound Microscope, and Leica Dissection Microscope. 